\title{
A NATO VJTF-be felajánlott Bundeswehr erők újgenerációs szoftverrádiói
}

\begin{abstract}
A BAAINBw ${ }^{1}$ 2019-ben a Puma lánctalpas gyalogsági harcjárművek harcértéknövelését célzó, 500000 euró értékủ szerződést kötött a Rheinmetall védelmi ipari óriáscéggel. A szerződés a NATO $\mathrm{VJTF}^{2}$ keretnemzeti kötelezettséghez, konkrétan a német System Panzergrenadier VJTF 2023 modernizációs program végrehajtásához [1] kötődik. A NATO NRF állományában 2016-ban 5000 fős létszámmal létrehozott VJTF, egy légi- és tengeri támogató-, valamint különleges múveleti és kibervédelmi egységekkel kiegészített, többnemzeti szárazföldidandár-méretú harccsoport. Vezetése keretnemzeti koncepcióban ${ }^{4}$, az Egyesült Királyság, Franciaország, Németország, Lengyelország, Olaszország, Spanyolország és Törökország éves rotációjával valósul meg. 2023-ban 12 hónapra ismét Németország tölti majd be a keretnemzet szerepét, vagyis a VJTF ismét német irányítás alá kerül.
\end{abstract}

A System Panzergrenadier VJTF 2023 projekt magába foglalja $41 \mathrm{db}$ Puma gyalogsági harcjármú képességnövelését, beleértve a Eurospike, a Rheinmetall, a Diehl Defence és a Rafael által fejlesztett, $152 \mathrm{~mm}$-es MELLS irányított páncéltörő rakétarendszerrel történő felszerelését, új digitális rádiók beépítését, a TacNet (Tactical Network) harcászati rendszer integrálását, valamint új nappali és hőkamerák, továbbá színes kijelzők beszerzését. A program a Puma gyalogsági harcjármüvek és az IdZ-ES ${ }^{5}$ projekt alapján felszerelt lövészkatonák számára egy hálózatközpontú harci környezetet hoz létre. A program része a katona fegyverén, egyéni védőfelszerelésén túl egy teljesen digitalizált eszközökkel ellátott híradó-informatikai rendszer is, amelyet beszéd-, videó- és más kommunikációs berendezések - mint például rádiókészülék, számítógép, sisakra telepített kijelző és navigációs berendezés - alkotnak. A VJTF 2023 program eredményeként a Puma gyalogsági harcjárművek harci képessége is jelentősen javul, a járművek és a jármúveket elhagyó lövészek hálózatba kapcsolása növeli azok harci hatékonyságát.

A Puma harcjármúvekből kiszálló lövészek raj-, szakasz-, és századszintű, IP-alapú beszéd- és adatkommunikációs igényeinek kielégítésére (1. ábra) a Bundeswehr a Rohde \& Schwarz elektronikai divíziójának SOVERON nevű kétsávos, VHF/UHF szoftverrádió-technológiááát választotta. A szoftverrádió (SDR - Software-Defined Radio) alapkoncepciója, hogy a nagyfrekvenciás részek kivételével valamennyi funkciót (hullámforma képzés, moduláció, titkosítás, vezérlés) szoftveresen, egy kellöen erős hardveren futó, tárolt programmal valósítják meg. Ez így rendkívül rugalmassá teszi a rendszert, a hardveren futtatott különféle szoftverek segítségével számos olyan alkalmazás is kialakítható, amelyre korábban dedikált céleszközök szolgál-
ÖSSZEFOGLALÁS: A cikk a NATO VJTF-be (a sajtó által „lándzsahegy-dandárnak" nevezett harccsoportba) felajánlott német Puma lánctalpas gyalogsági harcjárművek és a járműveket elhagyó - IdZ-ES (Infanterist der Zukunft Enhanced System) a jövő lövészkatonája felszereléscsomaggal ellátott - katonák számára biztosított újgenerációs, titkosított beszéd- és adatátvitelre alkalmas digitális rádiókat kívánja bemutatni.

KULCSSZAVAK: System Panzergrenadier VJTF 2023 modernizációs program, Puma gyalogsági harcjármü, IdZ-ES, SVFuA, SOVERON VR jármürádió; SOVERON HR kézi rádió; SOVERON WAVE hullámforma.
ABSTRACT: German Puma tracked fighting vehicles and the unmounted soldiers - supported by future soldiers equipment - get new-generation encrypted digital voice and data radios. These forces are offered to the NATO VJTF (commonly called „Spearhead Brigade). The goal of this article is the introduction of these devices.

KEY WORDS: System Panzergrenadier VJTF 2023 modernization program, Puma infantry fighting vehicle, IdZ-ES, SVFuA, SOVERON VR vehicle radio; SOVERON HR handheld radio; SOVERON WAVE waveform.

\footnotetext{
Nyugállományú mérnök alezredes. ORCID: 0000-0002-3732-4573
} 


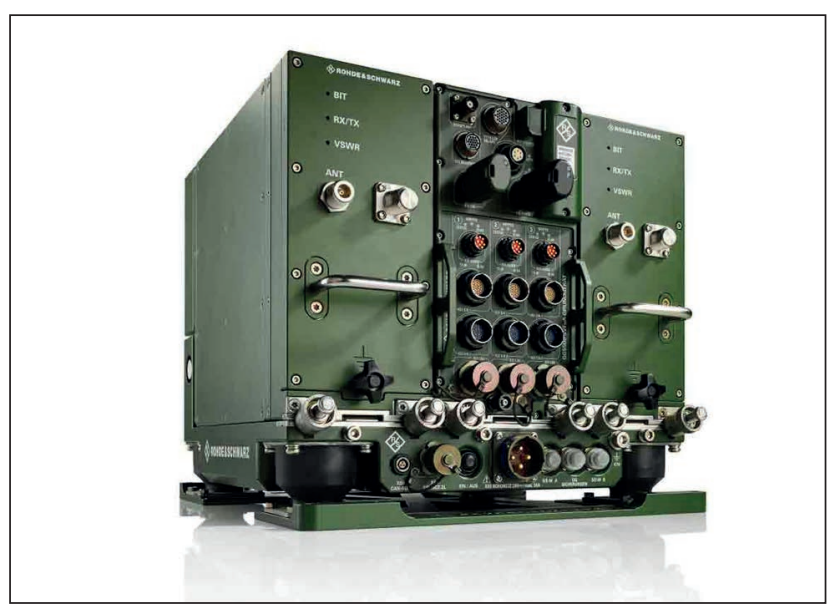

2. ábra. Az SVFuA rádiókommunikációs rendszer alapegysége [10]

tak. Mivel a tábori infokommunikációs rendszer valamennyi csomóponti eleme azonos hardverrel működik, nagyban csökkenek az üzemeltetési nehézségek és költségek.

A Rhode \& Schwartz SOVERON rádiókommunikációs rendszereket többcsatornás szoftverrádiók, és a hozzájuk tartozó nagy adatátviteli sebességü és zavarvédett hullámformák alkotják, amelyek képesek a nemzeti minősített adatokra vonatkozó követelményeken túl a NATO-titkos minősítési szintű információvédelem követelményeinek is megfelelni. A SOVERON VR (vehicle radio) jármübe épített rádió és a SOVERON HR (handheld radio) kézi rádió fejlesztése kifejezetten harcászati kommunikációs céllal történt. A készülékek interoperábilisak a Rhode \& Schwarz-tól a Bundeswehr által 2017-ben megrendelt, szoftverrádiótechnológián alapuló SVFuA (Streitkräftegemeinsame, verbundfähige Funkgeräte-Ausstattung) rendszerrel, amely a német fegyveres erők közös, hálózatalapú rádiórendszere. (2. ábra) A projekt részeként fejlesztik azokat a következő generációs mobil rádióberendezéseket, amelyek adaptív, keskeny- és szélessávú hullámformákkal csomópontokként, vagy végberendezésekként alkalmazhatók. Az új rádiók az interoperabilitás jegyében, ha szükséges, képesek együttműködni a német hadseregben még meglévő SEM rádiócsalád (SEM 80, SEM 90 stb.) analóg rádióival is.

A SOVERON szoftverrádiók hálózatalapú, nagy adatátviteli sebességű, zavarálló SOVERON WAVE hullámformákkal működnek. A hullámformacsalád minden tagja képes MANET (Mobile Ad hoc Network) eseti hálózat létesítésére. $\mathrm{Az}$ automatikusan felépülő lokális ad hoc adathálózatok

3. ábra. MANET mobil ad hoc hálózatmodell [14]

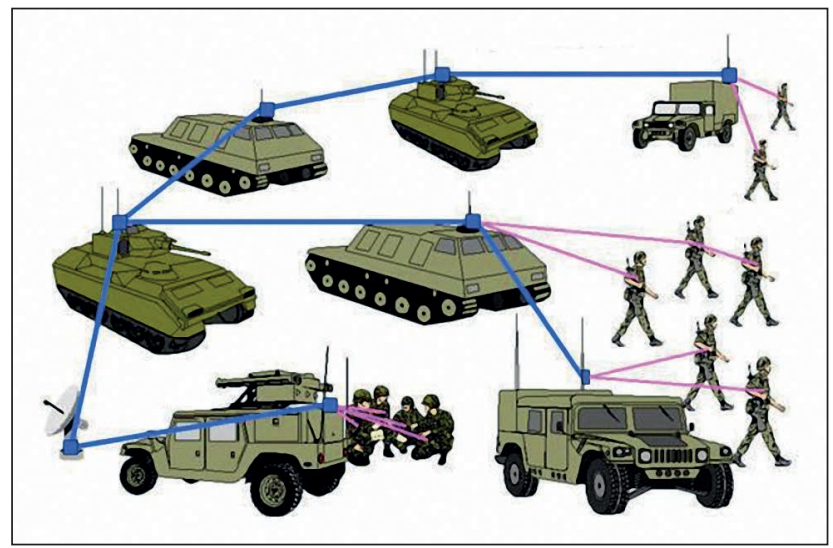

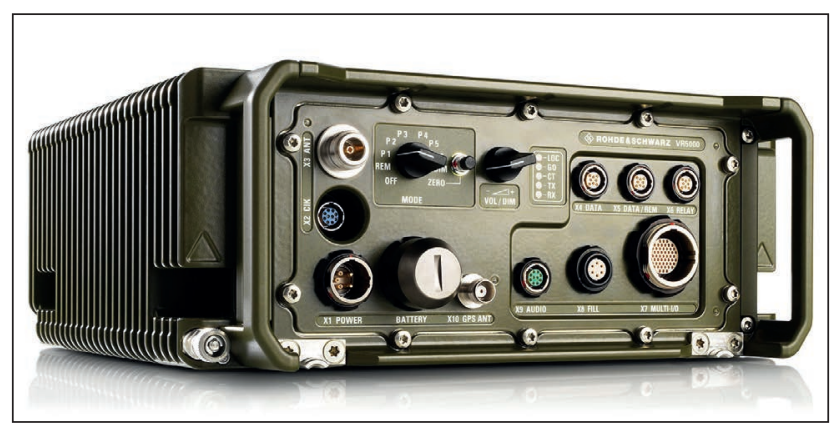

4. ábra. SOVERON VR harcászati jármürádió [12]

rádiós csomópontokból, és azokat összekötő rádiós átviteli utakból állnak. Az ilyen funkcióra képes rádiók csomópontként működnek, rajtuk keresztül történik az adatátvitel és a beszéd átvitele is, természetesen IP-alapon (3. ábra). A dinamikusan változó mindenkori hálózati topológia szerint egy adott csomópont egy másik, vagy több másik csomóponthoz is kapcsolódhat, és azzal kommunikálhat. A MANET-hálózatok nagy előnye a hálózatkiterjesztés, vagyis a rádióhálózat-hatósugár megtöbbszörözés képessége. További előny, hogy nincs szükség fix infrastruktúrára a csomópontok közötti átvitel megvalósításához. [14]

\section{SOVERON VR HARCÁSZATI JÁRMÜRÁDIÓ}

A SOVERON VR jármürádió a SOVERON szoftverrádiócsalád tagja (4. ábra). Egyidejű beszéd- és IP adatátviteli összeköttetés létesítésére alkalmas VHF/UHF kétsávos harcászati adó-vevő. Frekvenciatartománya 30-512 MHz. Adóteljesítménye (külső erősítő nélkül) $50 \mathrm{~W}$. Beépített GPS-vevővel ellátott. Hardver része megfelel az USA MILSTD (Military Standard) szabványsorozat követelményeinek, (1. táblázat) így alkalmas extrém körülmények között történő üzemeltetésre. Teljeskörű információvédelemmel, beszéd- és adattitkosítási képességgel rendelkezik. A rádió szélessávú, frekvenciaugratásos, szórt spektrumú adásmódjának a felderítése is problémás, ezért a lehallgatása és zavarása különösen nehéz.

A SOVERON VR járműrádió a Rhode \& Schwarz hullámformacsaláddal teljesen IP-képes, így könnyen integrálható a meglévő IPv4 hálózatokba. Valójában egy SCA 2.2.2. (Software Communications Architecture 2.2.2.) alapú, bővíthető szoftverkommunikációs rádióplatform, amely támogatja a szabványos, és a speciális Rohde \& Schwarz hullámformákat, továbbá megkönnyíti a hullámformák portolását. A SOVERON WAVE hullámforma-csomag MANET ad hoc hálózatépítő, és TCP/IP (Transmission Control Protocol/ Internet Protocol) forgalom-optimalizáló funkcióval, valamint COMSEC (COMmunication SECurity) nemzeti minősített adatokra vonatkozó és NATO-titkos minősítési szintű információvédelmi, továbbá TRANSEC (TRANsport SECurity) átvitelbiztonsági képességgel rendelkezik.

\section{SOVERON HR HARCÁSZATI KÉZI RÁDIÓ}

A SOVERON HR kézi rádió a SOVERON VR járműrádióhoz hasonlóan egyidejű beszéd- és adatátviteli összeköttetés létesítésére alkalmas, kétsávos VHF/UHF szoftverrádió, beépített GPS-szel (5. ábra). Egyedi módon, a harcjárművekből kiszállva tevékenykedő lövészek számára fejlesztették. Frekvenciatartománya ennek az eszköznek is $30-512 \mathrm{MHz}$, de az adóteljesítménye változtathatóan 5,2 vagy $0,2 \mathrm{~W}$. Ez a készülék is 
1. táblázat. SOVERON VR jármürádió föbb müszaki paraméterei (a [15] alapján a szerző szerkesztése)

\begin{tabular}{|c|c|}
\hline \multicolumn{2}{|c|}{$\begin{array}{c}\text { Frekvenciatartomány, vevőérzékenység, kimenő } \\
\text { teljesítmény }\end{array}$} \\
\hline Frekvenciatartomány & $30-512 \mathrm{MHz}$ \\
\hline Vevőérzékenység & $\begin{array}{l}\text { F3E érzékenység }<-112 \mathrm{dBm} \\
\text { A3E érzékenység }<-112 \mathrm{dBm}\end{array}$ \\
\hline Kimenő teljesítmény & $50 \mathrm{~W}$ \\
\hline \multicolumn{2}{|c|}{ Hőmérséklettartomány } \\
\hline Üzemi hőmérséklet & $-25 C^{\circ}$ és $+55 C^{\circ}$ között \\
\hline $\begin{array}{l}\text { Megengedett } \\
\text { hőmérséklet }\end{array}$ & $-40 \mathrm{C}^{\circ}$ és $+71 \mathrm{C}^{\circ}$ között \\
\hline Tárolási hőmérséklet & $-46 C^{\circ}$ és $+90 \mathrm{C}^{\circ}$ között \\
\hline \multicolumn{2}{|c|}{ Környezetállósági és EMC specifikációk } \\
\hline \multicolumn{2}{|c|}{$\begin{array}{c}\text { A MIL-STD-810H és a MIL-STD-465G szabványnak } \\
\text { megfelelők }\end{array}$} \\
\hline \multicolumn{2}{|c|}{ Tápfeszültség } \\
\hline $\begin{array}{l}\text { Névleges üzemi } \\
\text { feszültség }\end{array}$ & $26,5 \mathrm{~V}$ \\
\hline $\begin{array}{l}\text { Üzemi } \\
\text { feszültségtartomány }\end{array}$ & $18-33 \mathrm{~V}$ \\
\hline \multicolumn{2}{|c|}{ Hullámformák } \\
\hline \multicolumn{2}{|c|}{$\begin{array}{l}\text { 1) STANAG-ekkel szabványos hullámformák; } \\
\text { 2) SOVERON WAVE hullámforma; } \\
\text { 3) Rohde \& Schwarz® SECOS hullámforma }\end{array}$} \\
\hline \multicolumn{2}{|c|}{ SOVERON WAVE hullámforma-jellemzők } \\
\hline $\begin{array}{l}\text { Adatátviteli sebességek } \\
\text { a sávszélesség } \\
\text { függvényében }\end{array}$ & $\begin{array}{l}\text { SOVERON WAVE AJ-NB } \\
110 \text { kbps ( } 25 \text { kHz-en); } \\
\text { SOVERON WAVE AJ-WB } \\
630 \text { kbps ( } 250 \text { kHz-en); } \\
\text { SOVERON WAVE WB } \\
2100 \text { kbps (500 kHz-en) }\end{array}$ \\
\hline \multicolumn{2}{|c|}{ Egyéb hullámforma specifikációk } \\
\hline $\begin{array}{r}\text { MANet ad hoc hálóz } \\
\text { optimalizáló funkció; CO } \\
\text { és TRANSEC átı }\end{array}$ & $\begin{array}{l}\text { atépítő- és TCP/IP forgalom } \\
\text { MSEC kommunikációbiztonsági } \\
\text { itelbiztonsági képesség }\end{array}$ \\
\hline
\end{tabular}

megfelel a vonatkozó MIL-STD kritériumoknak (2. táblázat). SOVERON HR kézi rádió a SOVERON WAVE TNW (The Next Wave) frekvenciaugratásos hullámforma által kapcsolódhat a SOVERON VR jármürádiókhoz. Ez a hullámforma rugalmasan integrálható IP-alapú rádiórendszerekbe. A SOVERON WAVE TNW hullámforma MANET ad hoc hálózatépítő funkcióval, COMSEC nemzeti minősített adatokra vonatkozó és NATOtitkos minősítési szintű információvédelmi, valamint TRANSEC átvitelbiztonsági képességgel rendelkezik.

A harcjárművekből kiszálló lövészek számára kis méretű és tömegü, alacsony energiafogyasztású, magas fokú energiahatékonysággal, és nagy kapacitású akkumulátorral működő eszköz szükséges. A SOVERON HR kézi rádió megfelel ezeknek a követelményeknek. Nagyban növeli a lövészek autonómiáját azáltal, hogy több mint 12 órás akkumulátor-üzemidő mellett, akár 7 km hatótávolságú rádiókommunikációt is lehetővé tesz.
2. táblázat. A SOVERON HR kézi rádió föbb müszaki paraméterei (A [15] alapján a szerző szerkesztése)

\begin{tabular}{|c|c|}
\hline \multicolumn{2}{|c|}{$\begin{array}{l}\text { Frekvenciatartomány, kimenő teljesítmény, } \\
\text { hatótávolság }\end{array}$} \\
\hline Frekvenciatartomány & $30-512 \mathrm{MHz}$ \\
\hline Hatótávolság & $\begin{array}{l}\text { Legfeljebb } 7 \text { km közvetlen } \\
\text { lefedettség, } \\
\text { amely MANET mobil } \\
\text { ad-hoc hálózat funkcióval } \\
\text { növelhető }\end{array}$ \\
\hline Kimenő teljesítmény & $5 / 2 / 0,2 \mathrm{~W}$ \\
\hline \multicolumn{2}{|c|}{ Méret-, tömeg- és energiaadatok } \\
\hline Méretek & $80 \mathrm{~mm} \times 219 \mathrm{~mm} \times 42 \mathrm{~mm}$ \\
\hline \begin{tabular}{|l} 
Tömeg \\
(akkumulátorral együtt)
\end{tabular} & $\sim 1,2 \mathrm{~kg}$ \\
\hline Akkumulátor üzemidő & $>12 \mathrm{~h}$ \\
\hline \multicolumn{2}{|c|}{ Hullámformák } \\
\hline \multicolumn{2}{|c|}{ Fix frekvencás és SOVERON WAVE TNW } \\
\hline \multicolumn{2}{|c|}{ SOVERON WAVE TNW hullámforma-jellemzők } \\
\hline \multicolumn{2}{|c|}{$\begin{array}{l}\text { AES (Advanced Encryption Standard) kódolás szerinti } \\
\text { COMSEC kommunikáció-biztonság; beszéd- és IP-alapú } \\
\text { adatátvitel; TRANSEC átvitelbiztonság; MANET ad hoc } \\
\text { hálózatépítés; Interoperabilitás }\end{array}$} \\
\hline \multicolumn{2}{|c|}{ Hőmérséklet-tartomány } \\
\hline Tárolási hőmérséklet & $\begin{array}{l}-40 \mathrm{C}^{\circ} \text { és }+71 \mathrm{C}^{\circ} \\
\text { tartományban }\end{array}$ \\
\hline Üzemi hőmérséklet & $\begin{array}{c}-30 \mathrm{C}^{\circ} \text { és }+60 \mathrm{C}^{\circ} \\
\text { tartományban }\end{array}$ \\
\hline \multicolumn{2}{|c|}{$\begin{array}{l}\text { Környezetállósági specifikációk a MIL-STD-810H } \\
\text { szabvány szerint, elektromágneses specifikációk a } \\
\text { MIL-STD-465G szabványnak megfelelnek }\end{array}$} \\
\hline
\end{tabular}

5. ábra. SOVERON HR kézi rádió [16]

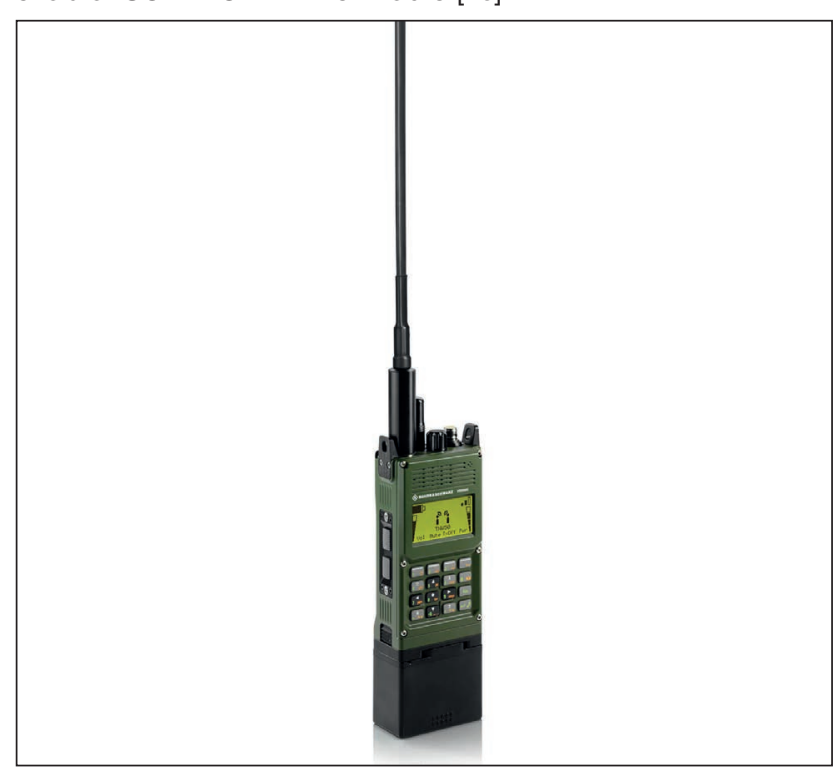




\section{ÖsSzEGzÉs}

A Rohde \& Schwarz szoftverrádiókat kifejezetten harcászati kommunikációs célra tervezték. A „SOVERON rendszermegoldás" nagy adatátviteli sebességű és interferenciamentes SOVERON WAVE hullámformákkal müködik. A gyártó szerint a SOVERON hullámformacsalád minden eszköze MANET funkciókkal bír. Az ilyen képességű rádióeszközök dinamikusan változó topológia mellett is transzparens felületet szolgáltatnak az IP eszközök részére, és még extrém körülmények között is megbízható kommunikációt biztosítanak. A jelenleg még rendszerben álló analóg harcászati rádiók SOVERON digitális készülékekre történő cseréje a jelenlegi tervek szerint még 2022-ben magvalósul.

\section{HivATKOZOTT IRODALOM}

[1] Janes.com. „German Lead Contribution to VJTF 2023 to Be Modernised". Elérés 2021. március 17. https:// www.janes.com/defence-news/news-detail/germanlead-contribution-to-vjtf-2023-to-be-modernised;

[2] KG, Rohde \& Schwarz GmbH \& Co. „Softwarebasierte Funkgeräte - Sichere Kommunikation”. Elérés 2021. március 3. https://www.rohde-schwarz.com/at/ produkte/aerospace-defense-security/ softwarebasierte-funkgeraete/pg-softwarebasiertefunkgeraete 64225.html;

[3] Bundeswehr Journal. „Software Defined Radios „Soveron“ von Rohde \& Schwarz -...”, 2019. július 23. https://www.bundeswehr-journal.de/2019/softwaredefined-radios-soveron-von-rohde-schwarz/;

[4] Ruzhelnyk, Olga. „Rheinmetall - Leading Supplier of Soldier Systems and Expert Partner for NetworkEnabled Operations". EDR Magazine (blog), 2019. szeptember 10. https://www.edrmagazine. eu/\%e2\%96\%ba-rheinmetall-leading-supplier-ofsoldier-systems-and-expert-partner-for-networkenabled-operations;

[5] Hardthöhenkurier Online. „Eurosatory 2018: Rohde \&amp; Schwarz präsentiert sich als Lösungsanbieter für Sichere Kommunikation im taktischen Einsatz". Elérés 2021. március 3. https://www. hardthoehenkurier.de/index.php/news/9-news/1734eurosatory-2018-rohde-schwarz-praesentiert-sich-alsloesungsanbieter-fuer-sichere-kommunikation-imtaktischen-einsatz;

[6] ES\&T. „Neue VHF/UHF-Funkgeräte für die VJTF (L) 2023". ESUT - Europäische Sicherheit \& Technik, 2019. július 22. https://esut.de/2019/07/meldungen/ ruestung2/14052/neue-vhf-uhf-funkgeraete-fuer-dievjtf-I-2023/;

[7] Hardthöhenkurier Online. „Deutsches Heer setzt auf Rohde \& Schwarz". Elérés 2021. március 3. https:// www.hardthoehenkurier.de/index.php/news/9news/2055-deutsches-heer-setzt-auf-rohde-schwarz;

[8] „Digitalisierung der VJTF2023: Neue Software, alte Hardware - Augen geradeaus!" Elérés 2021. március 3. https://augengeradeaus.net/2018/12/digitalisierungder-vjtf2023-neue-software-alte-hardware/;

[9] Ruzhelnyk, Olga. „"System Panzergrenadier”: Rheinmetall Modernizing Puma Infantry Fighting Vehicle and Other Equipment for NATO Spearhead VJTF 2023". EDR Magazine, 2019. július 22.

https://www.edrmagazine.eu/system-panzergrenadierrheinmetall-modernizing-puma-infantry-fighting- vehicle-and-other-equipment-for-nato-spearheadvjtf-2023;

[10] Armada International. „German Army Relies on Rohde \& Schwarz". Armada International (blog), 2019. augusztus 9.

https://armadainternational.com/2019/08/germanarmy-relies-on-rohde-schwarz/;

[11] Kim Feilcke. „Implementation of the capability requirements of the Puma infantry fighting vehicle in the Panzergrenadier system" ESUT - Europäische Sicherheit \& Technik, 2020. aug. 10. https://esut.de/en/2020/08/fachbeitraege/20769/ umsetzung-der-faehigkeitsforderungen-desschuetzenpanzers-puma-in-das-systempanzergrenadier;

[12] Rohde \& Schwarz International. „SOVERON® VR Vehicular Tactical Radio - Overview”. Elérés 2021. március 3. https://www.rohde-schwarz.com/pl/ product/sdtr-productstartpage 63493-30529.html;

[13] Rohde \& Schwarz. „SOVERON® VR Vehicular Tactical Radio: For vehicular and semi mobile platforms" Broschure and datasheet. Elérés 2021. március 3. https://cdn.rohde-schwarz.com.cn/pws/ dl_downloads/dl_common_library/dl_brochures_and datasheets/pdf_1/SOVERON-VR_fly_en_5215-004032_v0301.pdf;

[14] „A typical scenario of Communication in Mobile Adhoc Network" In: Joshi, Sachidananda S., és Sangappa Ramachandra Biradar. „Communication Framework for Jointly Addressing Issues of Routing Overhead and Energy Drainage in MANET". Procedia Computer Science 89 (2016): 57-63. https://doi.org/10.1016/j.procs.2016.06.009. https:// www.researchgate.net/

figure/A-typical-scenario-of-Communication-inMobile-Adhoc-Network_fig1_306362664;

[15] Rohde \& Schwarz. „SOVERON® HR Handheld Tactical Radio: For the dismounted soldier" Broschure and datasheet. Elérés 2021. március 3. https://scdn.rohde-schwarz.com/ur/pws/dl_ downloads/dl_common_library/dl_brochures_and datasheets/pdf_1/SOVERON-HR_fly_en_5215-817032_v0300.pdf;

[16] Rohde \& Schwarz GmbH \& Co. „SOVERON HR Starts on Road to Success". Elérés 2021. március 3. https://www.rohde-schwarz.com/hu/about/ news-press/all-news/soveron-hr-starts-on-road-tosuccess-press-release-detailpage_229356-934784. html.

\section{JeGYZETEK}

1 BAAINBw (Bundesamt für Ausrüstung, Informationstechnik und Nutzung der Bundeswehr) - a Bundeswehr Technológiai és Beszerzési Hivatala.

2 NATO VJTF (Very High Readiness Joint Task Force) - Nagyon Magas Készenlétű Összhaderőnemi Műveleti Erő.

3 NATO NRF (NATO Response Force) - NATO Reagáló Erők

4 A 2013-ban kialakított és 2014-ben elfogadott német javaslat szerint egyes nagy tagállamok alapvető stratégiai képességeket biztosítanak és fejlesztenek, míg a kisebb tagállamok a hiányzó résképességeket, területeket fedik le, és a szövetségesek fegyveres erőiket közösen, közös műveleti parancsnokság alatt alkalmazhatják (a szerk.). Bővebben: https://biztonsagpolitika.hu/ nato-netto/a-nato-walesi-csucstalalkozojanak-napirendje

5 IdZ-ES (Infanterist der Zukunft, Erweitertes System) a jövő lövészkatonája kibővített projekt. 